\title{
Pd-catalyzed cross-coupling reactions exhibiting catalyst turnover numbers (TONs) exceeding one million
}

\author{
Shiqing Xu, Nicholas L. Truex, Swathi Mohan, and Ei-ichi Negishi* \\ H. C. Brown Laboratories of Chemistry, Purdue University \\ 560 Oval Drive, West Lafayette, Indiana 47907-2084, USA \\ E-mail: negishi@purdue.edu
}

This paper is dedicated to Professor Keith Smith in recognition and appreciation of his pioneering contribution to the development of green organic synthesis

\begin{abstract}
Pd-catalyzed cross-coupling giving aryl-aryl, alkenyl-aryl, aryl-alkenyl, alkynyl-aryl, and alkynyl-alkenyl products exhibited ultra-high turnover numbers (TONs) of $0.7 \times 10^{7} \sim 0.69 \times 10^{9}$ by using organozincs generated in situ by treatment of the corresponding organolithiums with dry $\mathrm{ZnBr}_{2}$. Additionally, the hydrozirconation-Pd-catalyzed cross-coupling tandem processes via treatment of 1-alkynes with ${ }^{i} \mathrm{Bu}_{2} \mathrm{AlH}-\mathrm{ZrCp}_{2} \mathrm{Cl}_{2}$ followed by selective ( $\geq 98 \%$ ) alkenyl-alkenyl coupling with either $(E)$ - or (Z)-ethyl 3-bromoacrylate exhibited high TONs of $0.9 \times 10^{5} \sim 0.81 \times 10^{7}$. Furthermore, Pd-catalyzed cross-coupling of 2-thienylzinc bromide and 1iodo-4-nitrobenzene also showed a high TON of $0.87 \times 10^{5}$.
\end{abstract}

Keywords: Pd-catalyzed cross-coupling, Negishi coupling, cross-coupling involving aryl, alkenyl, alkynyl, and heteroaryl groups, Pd-catalyst turnover numbers, $\mathrm{Pd}(\mathrm{DPEphos}) \mathrm{Cl}_{2}$, PEPPSI-IPr, PEPPSI-IPent

\section{Introduction}

In any catalytic reaction, catalysts must be regenerated in their original forms. In reality, however, catalysts do become gradually decomposed and hence inactivated, resulting in finite turnover numbers (TONs hereafter). For "green" organic syntheses involving catalytic processes, catalyst TON is a critically important factor affecting the economical aspects of such processes. Several years ago, we found ${ }^{1}$ that various representative classes of Pd-catalyzed cross-coupling of the Negishi version using $\mathrm{Zn}$ as the metal countercation in the organometallic reagent, would display TONs up to around $10^{6}$. Even if a catalyst costs a million dollars $\left(\$ 10^{6}\right)$ per mol the effective cost of the catalyst per production of one mol of a desired organic product is a mere 
$\$ 1 / \mathrm{mol}$. On this basis, we opted to not pursue this matter beyond the TON level of $10^{6}$. Incidentally, the use of some other metal countercations under allegedly optimal conditions led to TONs up to $10^{5}$ (observed with $\mathrm{Al}, \mathrm{B}$, In, or $\mathrm{Zr}$ ) or in the range of $10^{3} \sim 10^{4}$ (observed with $\mathrm{Mg}$, $\mathrm{Mn}$, or $\mathrm{Sn})$.

More recently, we have been informed that, in view of potential toxicity concerns, it is desirable to further improve TONs of Pd-catalyzed cross-couplings beyond the $10^{6}$ level. On this basis and on the basis of our own scientific curiosity, we decided to pursue the TONs of representative $\mathrm{Pd}$-catalyzed cross-coupling reactions beyond the previously observed range of up to around $10^{6}$, focusing our attention on $\mathrm{Zn}$ and a few other superior metals, such as $\mathrm{Al}, \mathrm{B}$, and $\mathrm{Zr}$ as the metal counteractions.

\section{Results and Discussion}

In order to observe high TONs in a reliable manner, we paid careful attention to avoiding false results due to contamination of the reaction system or vessel with residual catalyst, and erratic results due to any other factors. The results of the determination of TONs of the cross-coupling reactions involving aryl-, alkenyl-, or alkynylzinc bromides with aryl- or alkenyl- iodides in the presence of catalytic amounts of $\mathrm{Pd}(\mathrm{DPEphos}) \mathrm{Cl}_{2}$ are summarized in Table 1. For each Entry, a series of runs were followed by a blank run executed without addition of the catalyst under otherwise the same conditions. In each case, no formation of the desired product was observed. Furthermore, the catalyst solutions were prepared by a series of ten-fold dilutions with dry THF for high internal consistency among a series of experiments.

A series of reactions were initially performed at $23{ }^{\circ} \mathrm{C}$. After observing product yields of $<65 \%$ over $24 \mathrm{~h}$, such reaction mixtures were heated to $70{ }^{\circ} \mathrm{C}$, and they were further examined, confirming product yields of $<65 \%$ even after $24 \mathrm{~h}$ at $70{ }^{\circ} \mathrm{C}$. The TON for each case, i.e., each Entry, was calculated based on the last run exhibiting $\geq 65 \%$ yield of the desired product. All five classes of Pd-catalyzed cross-couplings shown in Table 1 exhibited unprecedentedly high TONs of the order of $10^{7} \sim 10^{9}$. Many of the yield and TON figures represent averages of two or more runs. Moreover, each cross-coupling reaction was run at least at four catalyst concentration levels $\left(1 \sim 10^{-7} \mathrm{~mol} \%\right)$, and a blank run without addition of the catalyst was also examined under otherwise the same conditions to avoid false results due to contamination.

The bidentate phosphine ligand DPEphos, bis[(2-diphenylphosphino)phenyl] ether, ${ }^{2}$ is superior to some of the widely used monodentate phosphines, such as $\mathrm{PPh}_{3}$, and TFP [tris(2furyl)phosphine,$^{3}$ and the bidentate phosphine ligands, including dppf [1,1'bis(diphenylphosphino)ferrocene $]^{4}$, at low catalyst loading levels. The $\mathrm{Pd}(\mathrm{DPEphos}) \mathrm{Cl}_{2^{-}}$ catalyzed cross-coupling reaction of $\mathrm{PhZnBr}(\mathrm{LiBr})$ with $p$-Tol-I exhibited an unprecedentedly high TON of $0.69 \times 10^{9}$. Although not listed in Table 1 , the previously observed ${ }^{1}$ TON of the reaction of $\mathrm{PhZnBr}(\mathrm{LiBr})$ with $p$-Tol-I catalyzed by $\mathrm{Pd}(\mathrm{dppf}) \mathrm{Cl}_{2}$ was $0.35 \times 10^{7}$. The use of $\mathrm{Ni}\left(\mathrm{PPh}_{3}\right)_{2} \mathrm{Cl}_{2}$ in this reaction was also briefly investigated..$^{5}$ The desired biaryl was obtained in 
$98 \%$ yield with $1 \mathrm{~mol} \%$ of $\mathrm{Ni}\left(\mathrm{PPh}_{3}\right)_{2} \mathrm{Cl}_{2}$. However, the yield decreased to $49 \%\left(24 \mathrm{~h}\right.$ at $\left.70{ }^{\circ} \mathrm{C}\right)$ at the $0.1 \mathrm{~mol} \%$ level.

Table 1. Reaction of aryl-, alkenyl-, and alkynylzinc derivatives with aryl and alkenyl iodides in the presence of $\mathrm{Pd}(\mathrm{DPEphos}) \mathrm{Cl}_{2}$

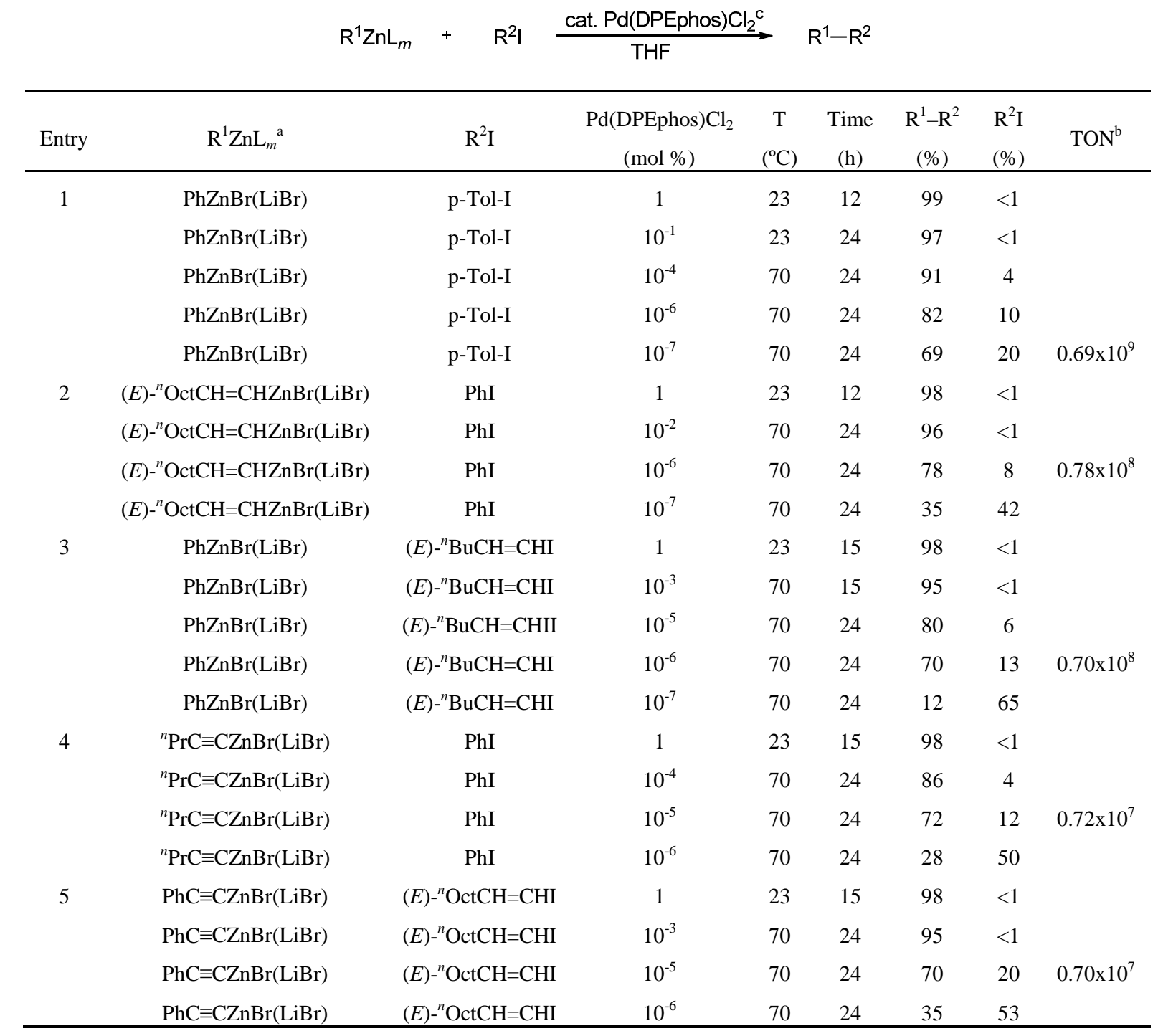

${ }^{\mathrm{a}} \mathrm{R}^{1} \mathrm{ZnBr}(\mathrm{LiBr})$ indicates that it was generated in situ by treating $\mathrm{R}^{1} \mathrm{Li}$ with dry $\mathrm{ZnBr}_{2}$. ${ }^{\mathrm{b}} \mathrm{TON}$ was caculated for the case where the yield of $R^{1}-R^{2}$ exceeds $65 \%$ with the lowest amount of $\operatorname{Pd}(\mathrm{DPEphos}) \mathrm{Cl}_{2}$. ${ }^{\mathrm{c}} \mathrm{Pd}(\mathrm{DPEphos}) \mathrm{Cl}_{2}$ :

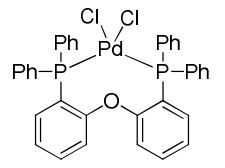


The alkenyl-aryl coupling of $(E)-{ }^{n} \mathrm{OctCH}=\mathrm{CHZnBr}(\mathrm{LiBr})$ with $\mathrm{PhI}$ and the aryl-alkenyl coupling of $\mathrm{PhZnBr}(\mathrm{LiBr})$ with $(E)-{ }^{n} \mathrm{BuCH}=\mathrm{CHI}$ exhibited TONs of $0.78 \times 10^{8}$ and $0.70 \times 10^{8}$, respectively. TONs of $0.72 \times 10^{7}$ and $0.70 \times 10^{7}$ were observed in the cases of the alkynyl-aryl coupling of ${ }^{n} \mathrm{PrC} \equiv \mathrm{CZnBr}(\mathrm{LiBr})$ with $\mathrm{PhI}$ and the alkynyl-alkenyl coupling of $\mathrm{PhC} \equiv \mathrm{CZnBr}(\mathrm{LiBr})$ with $(E)-{ }^{n} \mathrm{OctCH}=\mathrm{CHI}$, respectively.

Recently, we developed a highly selective synthesis of conjugated dienoic and trienoic esters via alkyne elementometalation-Pd-catalyzed cross-coupling tandem processes. ${ }^{6}$ (E)-Alkenylzirconium derivatives generated in situ by treating 1-alkynes with ${ }^{i} \mathrm{Bu}_{2} \mathrm{AlH}-\mathrm{ZrCp}_{2} \mathrm{Cl}_{2}{ }^{7}$ undergo highly stereoselective alkenyl-alkenyl coupling with either ethyl $(E)^{8}$ - or $(Z)^{9}$-3-bromoacrylate in the presence of $1 \mathrm{~mol} \%$ of PEPPSI-IPr (pyridine-enhanced precatalyst preparation stabilization and initiation) ${ }^{10}$ to provide various conjugated dienoic and trienoic esters in $\geq 98 \%$ stereoselectivity. High TONs of $0.60 \sim 0.65 \times 10^{5}$ in hydrometalation-Pd(dppf)Cl $\mathrm{Cl}_{2}$-catalyzed crosscoupling tandem reactions involving $\mathrm{B}, \mathrm{Al}$, and $\mathrm{Zr}\left(\mathrm{ZnBr}_{2}\right.$ was added after hydrometalation) were observed. ${ }^{1}$

For economic and other reasons, it is desirable to use the bromides as coupling partners. In general, however, the Pd-catalyzed cross-coupling reactions of organic bromides have been found to be more sluggish and, hence, less favorable than the corresponding reactions of iodides. To determine the efficiency of hydrozirconation-Pd-catalyzed cross-coupling tandem processes recently developed in our laboratories, ${ }^{6}$ we examined TONs of the cross-coupling reactions between $(E)-{ }^{n} \mathrm{HexCH}=\mathrm{CHZrCp} 2 \mathrm{Cl}$ with ethyl $(E)$ - or $(Z)$-3-bromoacrylate, and the results are summarized in Table 2. Both reactions provided the desired conjugated dienoic esters ( $\geq 98 \%$ stereoselectivity) with high TONs of $0.81 \times 10^{7}$ and $0.90 \times 10^{5}$, respectively. 
Table 2. High turnover numbers observed in hydrozirconation-Pd-catalyzed cross-coupling tandem reactions producing conjugated dienes

$$
{ }^{n} \mathrm{Hex}=\stackrel{{ }^{i} \mathrm{Bu}_{2} \mathrm{AlH}_{\mathrm{ZrCp}} \mathrm{Cl}_{2}}{\longrightarrow}\left[{ }^{n} \mathrm{Hex} \leadsto \mathrm{ZrCp}_{2} \mathrm{Cl}\right] \stackrel{\begin{array}{c}
\text { cat. PEPPSI-IPrc } \\
\mathrm{RBr}, \mathrm{THF}
\end{array}}{\longrightarrow}{ }^{n} \mathrm{Hex} \leadsto{ }_{\mathrm{R}}
$$

\begin{tabular}{cccccccc}
\hline \multirow{2}{*}{ Entry } & $\mathrm{RBr}$ & $\begin{array}{c}\text { PEPPSI-IPr } \\
(\mathrm{mol} \%)\end{array}$ & $\begin{array}{c}\mathrm{T} \\
\left({ }^{\circ} \mathrm{C}\right)\end{array}$ & $\begin{array}{c}\text { Time } \\
(\mathrm{h})\end{array}$ & $\begin{array}{c}\text { Product } \\
(\%)\end{array}$ & $\begin{array}{c}\mathrm{RBr} \\
(\%)\end{array}$ & $\mathrm{TON}^{\mathrm{a}}$ \\
\hline 1 & $(Z)-\mathrm{BrCH}=\mathrm{CHCO}_{2} \mathrm{Et}$ & 1 & 23 & 15 & 98 & $<1$ & \\
& $(Z)-\mathrm{BrCH}=\mathrm{CHCO}_{2} \mathrm{Et}$ & $10^{-1}$ & 23 & 15 & 95 & 2 & \\
& $(Z)-\mathrm{BrCH}=\mathrm{CHCO}_{2} \mathrm{Et}$ & $10^{-3}$ & 23 & 15 & 50 & 50 & \\
& & & $70^{\mathrm{b}}$ & 24 & 90 & 5 & $0.90 \times 10^{5}$ \\
& & & 23 & 15 & 10 & 85 & \\
& $(Z)-\mathrm{BrCH}=\mathrm{CHCO}_{2} \mathrm{Et}$ & $10^{-4}$ & $70^{\mathrm{b}}$ & 24 & 40 & 50 & \\
& & & 23 & 15 & 98 & $<1$ & \\
& $(E)-\mathrm{BrCH}=\mathrm{CHCO}_{2} \mathrm{Et}$ & 1 & 23 & 15 & 97 & $<1$ & \\
& $(E)-\mathrm{BrCH}=\mathrm{CHCO}_{2} \mathrm{Et}$ & $10^{-1}$ & 23 & 24 & 88 & 6 & \\
& $(E)-\mathrm{BrCH}=\mathrm{CHCO}_{2} \mathrm{Et}$ & $10^{-3}$ & 70 & 24 & 81 & 12 & $0.81 \times 10^{7}$ \\
& $(E)-\mathrm{BrCH}=\mathrm{CHCO}_{2} \mathrm{Et}$ & $10^{-5}$ & 70 & 24 & 28 & 62 & \\
$(E)-\mathrm{BrCH}=\mathrm{CHCO}_{2} \mathrm{Et}$ & $10^{-6}$ & &
\end{tabular}

${ }^{\text {a }}$ TON was caculated for the case where the yield of coupled product exceeds $65 \%$ with the lowest amount of PEPPSI-IPr. ${ }^{b}$ The reaction was initially run at $23{ }^{\circ} \mathrm{C}$ for $15 \mathrm{~h}$, then was refluxed. ${ }^{c}$ PEPPSI-IPr:

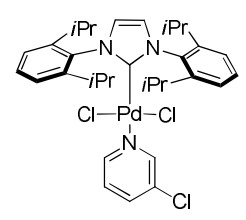


Table 3. High turnover numbers observed in Pd-catalyzed cross-coupling of arylzinc and heteroarylzinc reagents with aryl iodides

$$
\mathrm{R}^{1} \mathrm{ZnL}_{m}+\mathrm{R}^{2} \mathrm{I} \stackrel{\text { cat. } \mathrm{PdL}_{n}, \mathrm{THF}}{\longrightarrow} \mathrm{R}^{1}-\mathrm{R}^{2}
$$

\begin{tabular}{|c|c|c|c|c|c|c|c|c|c|}
\hline Entry & $\mathrm{R}^{1} \mathrm{ZnL}_{m}{ }^{\mathrm{a}}$ & $\mathrm{R}^{2} \mathrm{I}$ & $\begin{array}{c}\mathrm{PdL}_{n} \\
(\mathrm{~mol} \\
\%) \\
\end{array}$ & $\begin{array}{c}\mathrm{T} \\
\left({ }^{\circ} \mathrm{C}\right)\end{array}$ & $\begin{array}{l}\text { Time } \\
\text { (h) }\end{array}$ & $\begin{array}{l}\mathrm{R}^{1}- \\
\mathrm{R}^{2} \\
(\%) \\
\end{array}$ & $\begin{array}{l}\mathrm{R}^{2} \mathrm{I} \\
(\%)\end{array}$ & $\begin{array}{c}\mathrm{R}^{1}- \\
\mathrm{R}^{1} \\
(\%) \\
\end{array}$ & $\mathrm{TON}^{\mathrm{b}}$ \\
\hline \multirow[t]{4}{*}{$1^{\mathrm{c}}$} & $\mathrm{PhZnBr}(\mathrm{LiBr})$ & 4-iodobenzonitrile & 1 & 23 & 15 & 93 & $<1$ & 5 & \\
\hline & $\mathrm{PhZnBr}(\mathrm{LiBr})$ & 4-iodobenzonitrile & $10^{-3}$ & 70 & 24 & 88 & $<1$ & 10 & \\
\hline & PhZnBr(LiBr) & 4-iodobenzonitrile & $10^{-4}$ & 70 & 24 & 83 & $<1$ & 13 & $0.83 \times 10^{6}$ \\
\hline & $\mathrm{PhZnBr}(\mathrm{LiBr})$ & 4-iodobenzonitrile & $10^{-5}$ & 70 & 24 & 30 & 50 & 15 & \\
\hline \multirow[t]{5}{*}{$2^{\mathrm{d}}$} & 2-thienylzinc bromide & 1-iodo-4-nitrobenzene & $10^{-1}$ & 23 & 24 & 97 & $<1$ & 2 & \\
\hline & 2-thienylzinc bromide & 1-iodo-4-nitrobenzene & $10^{-2}$ & 70 & 24 & 95 & $<1$ & 3 & \\
\hline & 2-thienylzinc bromide & 1-iodo-4-nitrobenzene & $10^{-3}$ & 70 & 24 & 87 & 5 & 3 & $0.87 \times 10^{5}$ \\
\hline & 2-thienylzinc bromide & 1-iodo-4-nitrobenzene & $10^{-4}$ & 70 & 24 & 10 & 83 & 4 & \\
\hline & 2-thienylzinc bromide & 1-iodo-4-nitrobenzene & $10^{-3[\mathrm{c}]}$ & 70 & 24 & 32 & 60 & 5 & \\
\hline
\end{tabular}

a $\mathrm{R}^{1} \mathrm{ZnBr}(\mathrm{LiBr})$ indicates that it was generated in situ by treating $\mathrm{R}^{1} \mathrm{Li}$ with dry $\mathrm{ZnBr}_{2}$. ${ }^{\mathrm{b}} \mathrm{TON}$ was caculated for the case where the yield of $\mathrm{R}^{1}-\mathrm{R}^{2}$ exceeds $65 \%$ with the lowest amount of catalyst. ${ }^{\mathrm{c}} \mathrm{Pd}(\mathrm{DPEphos}) \mathrm{Cl}_{2}$ was used. ${ }^{\mathrm{d}}$ PEPPSI-IPent was used.

PEPPSI-IPent:

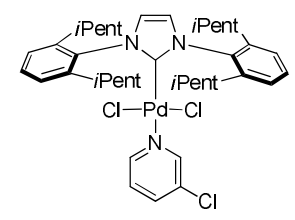

In order to illustrate the high tolerance of functional groups, we also examined the TON of the cross-coupling reaction of $\mathrm{PhZnBr}(\mathrm{LiBr})$ with 4-iodobenzonitrile (Table 3, entry 1) in the presence of $\mathrm{Pd}(\mathrm{DPEphos}) \mathrm{Cl}_{2}$. A high $\mathrm{TON}$ of $0.83 \times 10^{6}$ was also observed in this reaction to provide the coupled product [1,1'-biphenyl]-4-carbonitrile. However, some quantities of a homocoupled biphenyl side product were observed in the reactions.

Heterobiaryls have attracted significant attention from the scientific community due to their wide range of pharmacological activities. The Pd-catalyzed cross-coupling reaction provides a very efficient method for the preparation of such compounds. However, this procedure generally suffers from high catalyst loading due to palladium catalyst poisoning by sulfur- and nitrogencontaining compounds. Negishi cross-coupling reactions using organozincs of generally higher reactivity relative to other organometallic reagents are attractive alternatives for achieving high TONs for the synthesis of heteroaryl compounds, since they typically require milder reaction conditions and shorter reaction times. PEPPSI-IPent has been proven to be an excellent catalyst for these demanding cross-coupling reactions to produce an array of biaryl and heterobiaryl 
compounds bearing various functional groups in excellent yields under mild reaction conditions. ${ }^{11}$ In view of the importance of heterobiaryl compounds, we also examined the TON of the cross-coupling reaction of 2-thienylzinc bromide and 1-iodo-4-nitrobenzene in the presence of PEPPSI-IPent. As shown in entry 2 of Table 3, a high TON of $0.87 \times 10^{5}$ was obtained for the preparation of 2-(4-nitrophenyl)thiophene. In order to demonstrate the high efficiency of PEPPSI-IPent, the cross-coupling reaction of 2-thienylzinc bromide and 1-iodo-4nitrobenzene was also performed using $\mathrm{Pd}(\mathrm{DPEphos}) \mathrm{Cl}_{2}$ as catalyst under similar reaction conditions. With $10^{-3} \mathrm{~mol} \%$ of $\mathrm{Pd}(\mathrm{DPEphos}) \mathrm{Cl}_{2}$, 2-(4-nitrophenyl)thiophene was formed in $32 \%$ yield. While 2-(4-nitrophenyl)thiophene was formed in $87 \%$ yield using $10^{-3} \mathrm{~mol} \%$ of PEPPSIIPent. Some other solvents, such as DMF, THF/DMF (2:1), THF/NMP (2:1), and 1,4-dioxane, were also surveyed in this reaction, but there was little influence on the TON of this reaction.

\section{Conclusions}

1. Unprecedentedly high turnover numbers (TONs) of the order of $10^{7} \sim 10^{9}$ have been observed for aryl-aryl (up to $10^{9}$ ), alkenyl-aryl, i.e., $\mathrm{R}^{1} \mathrm{R}^{2} \mathrm{C}=\mathrm{CHM}+\mathrm{ArI}$, or aryl-alkenyl, i.e., ArM + $\mathrm{ICH}=\mathrm{CR}^{1} \mathrm{R}^{2}\left(0.70 \sim 0.78 \times 10^{8}\right)$, alkynyl-aryl, i.e., $\mathrm{RC} \equiv \mathrm{CM}+\mathrm{ArI}$, and alkynyl-alkenyl, i.e., $\mathrm{RC} \equiv \mathrm{CM}+\mathrm{ICH}=\mathrm{CR}^{1} \mathrm{R}^{2}\left(0.70 \sim 0.72 \times 10^{7}\right)$ cases of the Pd-catalyzed cross-coupling using organometals generated in situ by treatment of the corresponding organolithiums with dry $\mathrm{ZnBr}_{2}$. Although tentative, the observed order of aryl > alkenyl > alkynyl with respect to the observed TONs might be associated with the relative stabilities of the aryl, alkenyl, and alkynyl groups under the reaction conditions.

2. (E)-Alkenylzirconium derivatives generated in situ by treating 1-alkynes with ${ }^{i} \mathrm{Bu}_{2} \mathrm{AlH}$ $\mathrm{ZrCp}_{2} \mathrm{Cl}_{2}{ }^{7}$ undergo stereospecific $(\geq 98 \%)$ alkenyl-alkenyl coupling with either ethyl $(E)$ - or $(Z)$ 3-bromoacrylate to exhibit the high TONs of $0.81 \times 10^{7}$ and $0.90 \times 10^{5}$, respectively.

3. PEPPSI-IPent-catalyzed cross-coupling of 2-thienylzinc bromide and 1-iodo-4-nitrobenzene to produce heterobiaryl 2-(4-nitrophenyl)thiophene exhibits a high TON of $0.87 \times 10^{5}$.

4. Although not discussed in detail here, preliminary observations indicate that Pd-catalyzed cross-coupling with 1-halo-1-alkynes may not readily lead to the production of 1,2-disubstituted alkynes in high yields and high TONs. 


\section{Experimental Section}

General. All glassware was flame-dried under vacuum, and the reactions were conducted under argon. THF and diethyl ether were dried and distilled from sodium/benzophenone under argon. $\mathrm{ZnBr}_{2}$ was flame-dried in vacuo. $\mathrm{Pd}(\mathrm{DPEPhos}) \mathrm{Cl}_{2}$ was prepared by the standard method. ${ }^{12}$ PEPPSI-IPr, PEPPSI-IPent and 2-thienylzinc bromide solution were purchased from Aldrich and used as received. ${ }^{1} \mathrm{H}$ and ${ }^{13} \mathrm{C} \mathrm{NMR}$ spectra were recorded in $\mathrm{CDCl}_{3}$ on a Varian Inova-300 spectrometer. Chemical shifts are reported in parts per million (ppm) using $\mathrm{CHCl}_{3}$ as the reference peak. The reactions were monitored by gas chromatography (GC) using an HP 7890A GC and an HP-5 $(30 \mathrm{~m} \times 0.32 \mathrm{~mm}, 0.25 \mu \mathrm{m})$ capillary column, with appropriate hydrocarbons as internal standards. Thin-layer chromatography (TLC) was carried out on Merck Glass Silica Gel 60 F-254 plates. Flash chromatographic separations were performed with $230-400$ mesh silica gel 60 and hexanes.

Pd-catalyzed cross-coupling of aryl-, alkenyl-, or alkynylzincs with aryl or alkenyl iodides. Representative procedure A. 4-Methylbiphenyl. ${ }^{13}$ To a solution of iodobenzene $(265 \mathrm{mg}, 1.3$ $\mathrm{mmol})$ in THF $(2 \mathrm{~mL})$ cooled to $-78{ }^{\circ} \mathrm{C}$ was added dropwise ${ }^{n} \mathrm{BuLi}(0.52 \mathrm{~mL}, 2.5 \mathrm{M}$ in hexanes, $1.3 \mathrm{mmol})$. The resultant solution was stirred at $-78{ }^{\circ} \mathrm{C}$ for $30 \mathrm{~min}$, followed by addition of a solution of dry $\mathrm{ZnBr}_{2}(332 \mathrm{mg}, 1.3 \mathrm{mmol})$ in THF $(1 \mathrm{~mL})$. The mixture was stirred at $-78{ }^{\circ} \mathrm{C}$ for $10 \mathrm{~min}$, and warmed to $0{ }^{\circ} \mathrm{C}$ over $20 \mathrm{~min}$. 4-Iodotoluene (218 mg, $1 \mathrm{mmol}$ ) and $\mathrm{Pd}(\mathrm{DPEPhos}) \mathrm{Cl}_{2}$ $\left(100 \mu \mathrm{L}, 10^{-5} \mathrm{M}, 10^{-6} \mathrm{mmol}\right.$ in THF) were added, and the resultant mixture was heated at reflux. After $24 \mathrm{~h}, \mathrm{GC}$ analysis indicated the title compound was formed in $82 \%$ yield. The reaction mixture was quenched with water, extracted with ether, dried over anhydrous $\mathrm{MgSO}_{4}$, filtered, and concentrated. Flash chromatography (silica gel, hexane) afforded $134 \mathrm{mg}(80 \%)$ of the title compound. ${ }^{1} \mathrm{H}$ NMR $\left(300 \mathrm{MHz}, \mathrm{CDCl}_{3}\right) \delta 2.36(\mathrm{~s}, 3 \mathrm{H}), 7.21(\mathrm{~d}, J 7.9 \mathrm{~Hz}, 2 \mathrm{H}), 7.28(\mathrm{t}, J 7.3 \mathrm{~Hz}$, $1 \mathrm{H}), 7.39$ (t, J 7.3 Hz, $2 \mathrm{H}), 7.47(\mathrm{~d}, J 7.9 \mathrm{~Hz}, 2 \mathrm{H}), 7.55(\mathrm{~d}, J 7.8 \mathrm{~Hz}, 2 \mathrm{H}) ;{ }^{13} \mathrm{C} \mathrm{NMR}(75 \mathrm{MHz}$, $\left.\mathrm{CDCl}_{3}\right) \delta 21.0,126.9$ (3C), 126.9 (2C), 128.7 (2C), 129.4 (2C), 136.9, 138.3, 141.1.

(E)-Dec-1-enylbenzene. ${ }^{14}$ The title compound was prepared according to Representative procedure A except that $(E)$-1-iododecene and iodobenzene were used instead of iodobenzene and 4-iodotoluene. The reaction mixture was heated at reflux for $24 \mathrm{~h}$, and the title compound was obtained in $78 \%$ GLC yield. ${ }^{1} \mathrm{H}$ NMR $\left(300 \mathrm{MHz}, \mathrm{CDCl}_{3}\right) \delta 0.88(\mathrm{t}, J 6.8 \mathrm{~Hz}, 3 \mathrm{H}), 1.27-1.48$ (m, 12 H), 2.17-2.23 (m, 2 H), 6.19-6.26 (m, 1 H), 6.38 (d, J 15.6 Hz, 1 H), 7.15-7.40 (m, 5 H); ${ }^{13} \mathrm{C}$ NMR $\left(75 \mathrm{MHz}, \mathrm{CDCl}_{3}\right) \delta 14.1,22.7,29.3$ (2C), 29.4, 29.5, 31.9, 33.0, 125.8 (2C), 126.6, 128.4 (2C), 129.7, 131.1, 137.9 .

(E)-Hex-1-enylbenzene. ${ }^{14}$ The title compound was prepared according to Representative procedure A except that $(E)$-1-iodohexene was used instead of 4-iodotoluene. The reaction mixture was heated at reflux for $24 \mathrm{~h}$, and the title compound was obtained in 70\% GLC yield. ${ }^{1} \mathrm{H}$ NMR $\left(300 \mathrm{MHz}, \mathrm{CDCl}_{3}\right) \delta 0.96(\mathrm{~m}, 3 \mathrm{H}), 1.34-1.54(\mathrm{~m}, 4 \mathrm{H}), 2.24(\mathrm{q}, J 6.6 \mathrm{~Hz}, 2 \mathrm{H}), 6.20-$ $6.30(\mathrm{~m}, 1 \mathrm{H}), 6.40(\mathrm{~d}, J 15.6 \mathrm{~Hz}, 1 \mathrm{H}), 7.17-7.23(\mathrm{~m}, 1 \mathrm{H}), 7.28-7.38(\mathrm{~m}, 4 \mathrm{H}) ;{ }^{13} \mathrm{C} \mathrm{NMR}(75$ $\left.\mathrm{MHz}, \mathrm{CDCl}_{3}\right) \delta 13.9,22.2,31.5,32.7,125.8$ (2C), 126.7, 128.4 (2C), 129.7, 131.1, 137.9. 
Pent-1-ynylbenzene. ${ }^{15}$ The title compound was prepared according to Representative procedure A except that 1-pentyne and iodobenzene were used instead of iodobenzene and 4iodotoluene in the amount of $\mathrm{Pd}(\mathrm{DPEPhos}) \mathrm{Cl}_{2}\left(100 \mu \mathrm{L}, 10^{-4} \mathrm{M}, 10^{-5} \mathrm{mmol}\right)$. The reaction mixture was heated at reflux for $24 \mathrm{~h}$, and the title compound was obtained in 72\% GLC yield. ${ }^{1} \mathrm{H}$ NMR $\left(300 \mathrm{MHz}, \mathrm{CDCl}_{3}\right) \delta 1.06(\mathrm{t}, J 7.2 \mathrm{~Hz}, 3 \mathrm{H}), 1.58-1.70(\mathrm{~m}, 2 \mathrm{H}), 2.40(\mathrm{t}, J 6.9 \mathrm{~Hz}, 2 \mathrm{H})$, 7.25-7.30 (m, $3 \mathrm{H}), 7.39-7.42(\mathrm{~m}, 2 \mathrm{H}) ;{ }^{13} \mathrm{C} \mathrm{NMR}\left(75 \mathrm{MHz}, \mathrm{CDCl}_{3}\right) \delta 13.5,21.3,22.2,80.6$, 90.2, 124.0, 127.4, 128.1 (2C), 131.5 (2C).

(E)-Dodec-3-en-1-ynylbenzene. ${ }^{16}$ The title compound was prepared according to Representative procedure $\mathbf{A}$ except that phenylacetylene and $(E)$-1-iododecene were used instead of iodobenzene and 4-iodotoluene in the amount of $\mathrm{Pd}(\mathrm{DPEPhos}) \mathrm{Cl}_{2}\left(100 \mu \mathrm{L}, 10^{-4} \mathrm{M}\right.$, $10^{-5} \mathrm{mmol}$ ). The reaction mixture was heated at reflux for $24 \mathrm{~h}$, and the title compound was obtained in 70\% GLC yield. ${ }^{1} \mathrm{H}$ NMR $\left(300 \mathrm{MHz}, \mathrm{CDCl}_{3}\right) \delta 0.89(\mathrm{t}, J 6.9 \mathrm{~Hz}, 3 \mathrm{H}), 1.22-1.48(\mathrm{~m}$, $12 \mathrm{H}), 2.12-2.20$ (m, $2 \mathrm{H}), 5.70$ (dt, $J 15.6,1.8 \mathrm{~Hz}, 1 \mathrm{H}), 6.20-6.31(\mathrm{~m}, 1 \mathrm{H}), 7.27-7.32(\mathrm{~m}, 3 \mathrm{H})$, 7.40-7.45 (m, $2 \mathrm{H}) ;{ }^{13} \mathrm{C} \mathrm{NMR}\left(75 \mathrm{MHz}, \mathrm{CDCl}_{3}\right) \delta$ 14.0, 22.6, 28.7, 29.1, 29.2, 29.4, 31.8, 33.2, 87.8, 88.3, 109.5, 123.6, 127.7, 128.1(2C), 131.3(2C), 145.1.

Hydrozirconation-Pd-catalyzed cross-coupling tandem reactions of alkynes with alkenyl bromides. Representative procedure $B$. $(2 E, 4 E)$-Ethyl undeca-2,4-dienoate. ${ }^{6}$ To a solution of $\mathrm{ZrCp}_{2} \mathrm{Cl}_{2}$ (438 mg, $\left.1.5 \mathrm{mmol}\right)$ in THF $(4.5 \mathrm{~mL})$ was added dropwise a solution of ${ }^{i} \mathrm{Bu}_{2} \mathrm{AlH}(1.5$ $\mathrm{mL}, 1.0 \mathrm{M}$ solution in hexane, $1.5 \mathrm{mmol})$ at $0{ }^{\circ} \mathrm{C}$ in dark under argon atmosphere. After the resulting suspension was stirred at $0{ }^{\circ} \mathrm{C}$ for $30 \mathrm{~min}$, a solution of 1 -octyne $(0.19 \mathrm{~mL}, 1.3 \mathrm{mmol})$ in THF ( $2 \mathrm{~mL}$ ) was added, and the reaction mixture was warmed to $23{ }^{\circ} \mathrm{C}$ and stirred for $30 \mathrm{~min}$. To a solution of ethyl $(E)$-ethyl 3-bromoacrylate $(179 \mathrm{mg}, 1.0 \mathrm{mmol})$ and PEPPSI-IPr $(0.7 \mathrm{mg}$, $0.001 \mathrm{mmol})$ in THF $(3 \mathrm{~mL})$ was added the reaction mixture obtained above, and the resulting reaction mixture was stirred at $23{ }^{\circ} \mathrm{C}$ for $15 \mathrm{~h}$. GC analysis indicated that the title compound was formed in $97 \%$ yield. The reaction mixture was quenched with water and extracted with ether. The combined organic layers were dried over anhydrous $\mathrm{MgSO}_{4}$, filtered and concentrated. Flash chromatography (silica gel, 5\% ethyl acetate in hexanes) afforded $192 \mathrm{mg}$ (92\%) of the title compound with $\geq 98 \%$ isomeric purity determined according to ${ }^{1} \mathrm{H}$ NMR. ${ }^{1} \mathrm{H}$ NMR $(300 \mathrm{MHz}$, $\left.\mathrm{CDCl}_{3}\right) \delta 0.87(\mathrm{t}, J 7.0 \mathrm{~Hz}, 3 \mathrm{H}), 1.20-1.39(\mathrm{~m}, 9 \mathrm{H}), 1.40-1.45(\mathrm{~m}, 2 \mathrm{H}), 2.16(\mathrm{q}, J 7.1 \mathrm{~Hz}, 2 \mathrm{H})$, $4.18(\mathrm{q}, J 7.0 \mathrm{~Hz}, 2 \mathrm{H}), 5.77(\mathrm{~d}, J 15.3 \mathrm{~Hz}, 1 \mathrm{H}), 6.05-6.22(\mathrm{~m}, 2 \mathrm{H}), 7.25(\mathrm{dd}, J 15.3,10 \mathrm{~Hz}, 1$ $\mathrm{H}) ;{ }^{13} \mathrm{C} \mathrm{NMR}\left(75 \mathrm{MHz}, \mathrm{CDCl}_{3}\right) \delta 14.0,14.2,22.5,28.6,28.8,31.6,32.9,60.1,119.1,128.3$, $144.7,145.0,167.2$.

$(2 Z, 4 E)$-Ethyl undeca-2,4-dienoate. ${ }^{6}$ The title compound was prepared according to Representative procedure B except that (Z)-ethyl 3-bromoacrylate was used instead of (E)ethyl 3-bromoacrylate. The reaction mixture was stirred at $23{ }^{\circ} \mathrm{C}$ for $15 \mathrm{~h}$, and the title compound was obtained in $95 \%$ GLC yield. ${ }^{1} \mathrm{H}$ NMR $\left(300 \mathrm{MHz}, \mathrm{CDCl}_{3}\right) \delta 0.88(\mathrm{t}, J 7.0 \mathrm{~Hz}, 3 \mathrm{H}), 1.20-1.50$ $(\mathrm{m}, 11 \mathrm{H}), 2.19(\mathrm{q}, J 7.1 \mathrm{~Hz}, 2 \mathrm{H}), 4.18(\mathrm{q}, J 7.0 \mathrm{~Hz}, 2 \mathrm{H}), 5.55(\mathrm{~d}, J 11.4 \mathrm{~Hz}, 1 \mathrm{H}), 6.07$ (dt, $J$ 15.3, $7.3 \mathrm{~Hz}, 1 \mathrm{H}), 6.54(\mathrm{t}, J 11.1 \mathrm{~Hz}, 1 \mathrm{H}), 7.31-7.41(\mathrm{~m}, 1 \mathrm{H}) ;{ }^{13} \mathrm{C} \mathrm{NMR}\left(75 \mathrm{MHz}, \mathrm{CDCl}_{3}\right) \delta$ $14.0,14.2,22.5,28.7,28.9,31.6,32.9,59.7,115.3,126.8,145.3,145.7,166.5$. 
[1,1'-biphenyl]-4-carbonitrile. ${ }^{17}$ The title compound was prepared according to Representative procedure A except that 4-iodobenzonitrile was used instead of 4-iodotoluene. The reaction mixture was heated at reflux for $24 \mathrm{~h}$, and the title compound was obtained in 83\% GLC yield. ${ }^{1} \mathrm{H}$ NMR $\left(300 \mathrm{MHz}, \mathrm{CDCl}_{3}\right) \delta$ 7.46-7.51 (m, $\left.3 \mathrm{H}\right), 7.59-7.62(\mathrm{~m}, 2 \mathrm{H}), 7.68-7.74(\mathrm{~m}, 4 \mathrm{H}) ;{ }^{13} \mathrm{C}$ NMR $\left(75 \mathrm{MHz}, \mathrm{CDCl}_{3}\right) \delta 110.5,118.7,126.9$ (2C), 127.4 (2C), 128.4, 128.8 (2C), 132.3 (2C), 138.8, 145.2.

2-(4-nitrophenyl)thiophene. ${ }^{18}$ To a solution of 1-iodo-4-nitrobenzene (100 mg, $\left.0.4 \mathrm{mmol}\right)$ and PEPPSI-IPent $\left(0.3 \mathrm{mg}, 4 \times 10^{-4} \mathrm{mmol}\right)$ in THF $(1.5 \mathrm{~mL})$ was added 2-thienylzinc bromide solution $(1.12 \mathrm{~mL}, 0.5 \mathrm{M}$ in THF, $0.56 \mathrm{mmol})$, and the resulting reaction mixture was stirred at $23{ }^{\circ} \mathrm{C}$ for $24 \mathrm{~h}$. GC analysis indicated that the title compound was formed in $97 \%$ yield. The reaction mixture was quenched with water and extracted with ether. The combined organic layers were dried over anhydrous $\mathrm{MgSO}_{4}$, filtered and concentrated. Flash chromatography (silica gel, $10 \%$ ethyl acetate in hexanes) afforded $76 \mathrm{mg}(93 \%)$ of the title compound. ${ }^{1} \mathrm{H} \mathrm{NMR} \mathrm{(300} \mathrm{MHz,}$ $\left.\mathrm{CDCl}_{3}\right) \delta 7.14(\mathrm{dd}, J 5.1,3.9 \mathrm{~Hz}, 1 \mathrm{H}), 7.43(\mathrm{dd}, J 5.1,1.5 \mathrm{~Hz}, 1 \mathrm{H}), 7.46(\mathrm{dd}, J 3.9,1.5 \mathrm{~Hz}, 1 \mathrm{H})$, $7.71(\mathrm{dt},, J$ 8.7, $2.4 \mathrm{~Hz}, 2 \mathrm{H}), 8.21(\mathrm{dt},, J 9.0,2.4 \mathrm{~Hz}, 2 \mathrm{H}) ;{ }^{13} \mathrm{C} \mathrm{NMR}\left(75 \mathrm{MHz}, \mathrm{CDCl}_{3}\right) \delta 124.3$ (2C), 125.6, 125.8 (2C), 127.6, 128.6, 140.4, 141.4, 146.4.

\section{Acknowledgements}

This investigation was supported by Purdue University, in particular by the H. C. Brown Distinguished Professorship Fund (E. Negishi as the recipient). N. L. Truex was an undergraduate research participant. Contributions in related projects by H. Rao, J. Gao, and T. Tobrman are acknowledged.

\section{References}

1. Huang, Z.; Qian, M.; Babinski, D. J.; Negishi, E. Organometallics 2005, 24, 475.

2. Kranenburg, M.; van der Burgt, Y. E. M.; Kamer, P. C. J.; van Leeuwen, P. W. N. M.; Goubitz, K.; Fraanje, J. Organometallics 1995, 14, 3081.

3. Farina, V.; Baker, S. R.; Sapino, C. Tetrahedron Lett. 1988, 29, 6043.

4. Hayashi, T.; Konishi, M.; Kobori, Y.; Kumada, M.; Higuchi, T.; Hirotsu, K. J. Am. Chem. Soc. 1984, 106, 158.

5. Negishi, E.; King, A. O.; Okukado, N. J. Org. Chem. 1977, 42, 1821.

6. Wang, G.; Mohan, S.; Negishi, E. Proc. Natl. Acad. Sci. USA 2011, 108, 11344.

7. Huang, Z.; Negishi, E. Org. Lett. 2006, 8, 3675.

8. Weir, J. R.; Patel, B. A.; Heck, R. F. J. Org. Chem. 1980, 45, 4926.

9. Ma, S.; Lu, X. J. Chem. Soc., Chem. Commun. 1990, 22, 1643.

10. Kantchev, E. A. B.; O’Brien, C. J.; Organ, M. G. Angew. Chem. Int. Ed. 2007, 46, 2768. 
11. (a) Çalimsiz, S.; Sayah, M.; Mallik, D.; Organ, M. G. Angew. Chem. Int. Ed. 2010, 49, 2014. (b) Valente, C.; Çalimsiz, S.; Hoi, K. H.; Mallik, D.; Sayah, M.; M. G. Organ, Angew. Chem. Int. Ed. 2012, 51, 3314.

12. Kranenburg, M.; Kamer, P. C. J.; van Leeuwen P. W. N. M. Eur. J. Inorg. Chem. 1998, 155.

13. Lee, P. H.; Lee, S. W.; Seomoon, D. Org. Lett. 2003, 5, 4963.

14. Terao, J.; Kato, Y.; Kambe, N. Chem. Asian J. 2008, 3, 1472.

15. Umeda, R.; Yuasa, T.; Anahara, N.; Nishiyama, Y. J. Organomet. Chem. 2011, 696, 1916.

16. Peyrat, J.-F.; Thomas, E.; L'Hermite, N.; Alami, M.; Brion, J.-D. Tetrahedron Lett. 2003, 44, 6703.

17. Grossman, O.; Gelman, D. Org. Lett. 2006, 8, 1189.

18. Chang, Y. J.; Chou, P-T.; Lin, S-Y.; Watanabe, M.; Liu, Z-Q.; Lin, J-L.; Chen, K-Y.; Sun, SS.; Liu, C-Y.; Chow, T. J. Chem. Asian J. 2012, 7, 572. 